\title{
$(4,0)$ Isomer
}

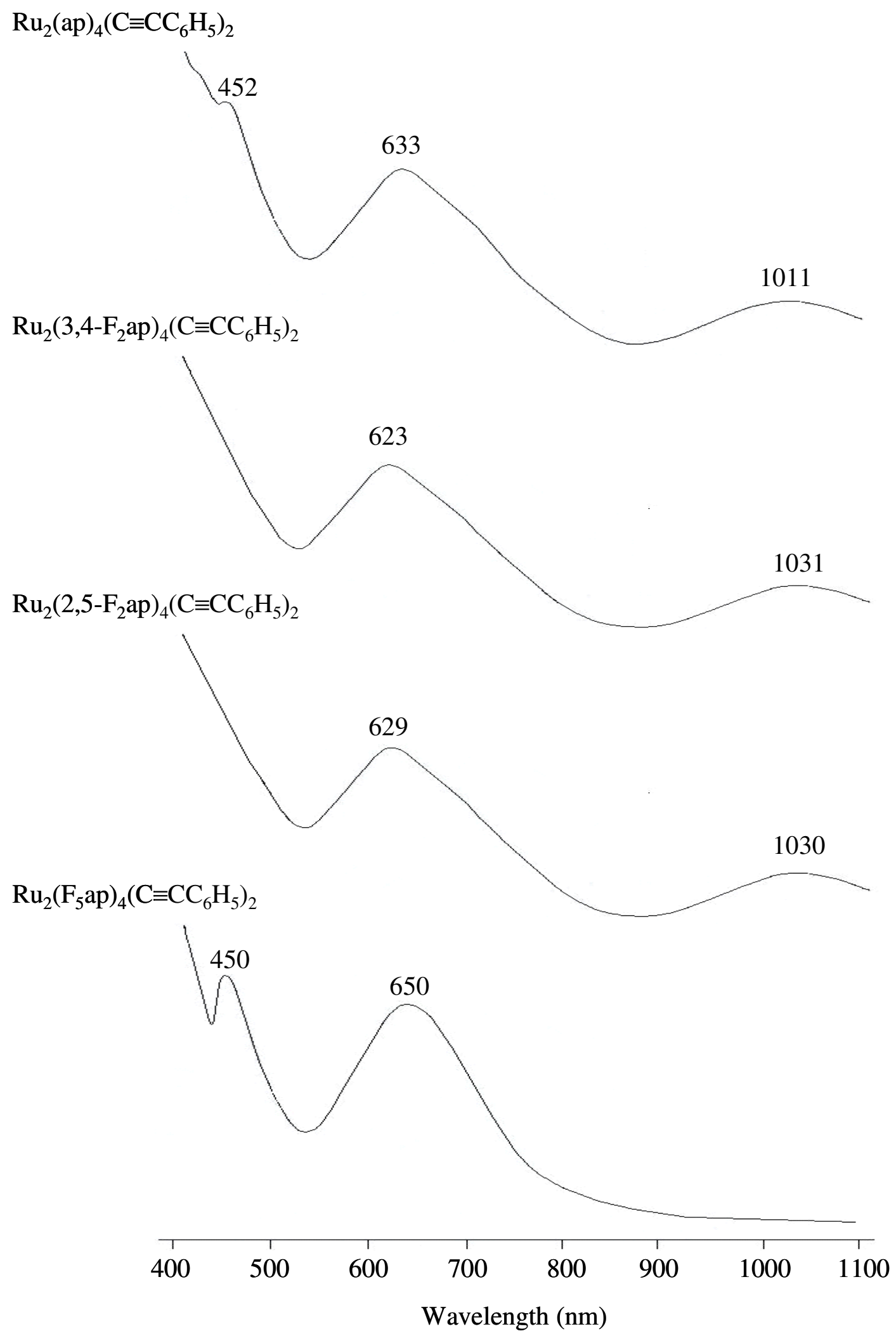

Figure S1. UV - visible Spectra of $(4,0) \mathrm{Ru}_{2}(\mathrm{~L})_{4}\left(\mathrm{C} \equiv \mathrm{CC}_{6} \mathrm{H}_{5}\right)_{2}$ in $\mathrm{CH}_{2} \mathrm{Cl}_{2}$. 